Research, part of a Special Feature on Networking the Environment: Social Network Analysis in Environmental Management and Local Ecological Knowledge Studies

\title{
Social organization influences the exchange and species richness of medicinal plants in Amazonian homegardens
}

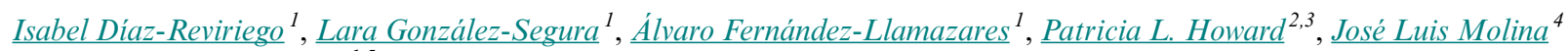 \\ and Victoria Reves-García ${ }^{1,5}$
}

\begin{abstract}
Medicinal plants provide indigenous and peasant communities worldwide with means to meet their healthcare needs. Homegardens often act as medicine cabinets, providing easily accessible medicinal plants for household needs. Social structure and social exchanges have been proposed as factors influencing the species diversity that people maintain in their homegardens. Here, we assess the association between the exchange of medicinal knowledge and plant material and medicinal plant richness in homegardens. Using Tsimane' Amazonian homegardens as a case study, we explore whether social organization shapes exchanges of medicinal plant knowledge and medicinal plant material. We also use network centrality measures to evaluate people's location and performance in medicinal plant knowledge and plant material exchange networks. Our results suggest that social organization, specifically kinship and gender relations, influences medicinal plant exchange patterns significantly. Homegardens total and medicinal plant species richness are related to gardeners' centrality in the networks, whereby people with greater centrality maintain greater plant richness. Thus, together with agroecological conditions, social relations among gardeners and the culturally specific social structure seem to be important determinants of plant richness in homegardens. Understanding which factors pattern general species diversity in tropical homegardens, and medicinal plant diversity in particular, can help policy makers, health providers, and local communities to understand better how to promote and preserve medicinal plants in situ. Biocultural approaches that are also gender sensitive offer a culturally appropriate means to reduce the global and local loss of both biological and cultural diversity.
\end{abstract}

Key Words: exchange networks; gender; plant diversity; social networks analysis; tropical homegardens; Tsimane'

\section{INTRODUCTION}

Medicinal plants provide locally accessible, culturally appropriate, and economically affordable healthcare options for people with scarce access to biomedical healthcare systems. Indeed, most indigenous and peasant communities meet their primary healthcare needs through the use of medicinal plants. While some medicinal plants are obtained from the wild, many are also obtained from agricultural fields and homegardens, both for household consumption and for sale (e.g., Bernholt et al. 2009, Aceituno-Mata 2010, Thomas and van Damme 2010, Yang et al. 2014). In particular, tropical homegardens support high species diversity and help communities to meet health needs, constituting in situ germplasm banks, biodiversity reservoirs, and medicine cabinets (Finerman and Sackett 2003, Huai and Hamilton 2009).

\section{Diversity in homegardens}

Tropical homegardens are renowned for their typically high levels of biological diversity. This species diversity is the result of gardeners' meticulous selection and management, which is aimed at providing products they consider to be important to subsistence and livelihoods (Kumar and Nair 2006). Homegarden diversity partly depends on climatic conditions, altitude, size and age of the garden, remoteness from urban centers, and village size, among other factors (Wezel and Bender 2003, Kehlenbeck and Maass 2004, Wezel and Ohl 2005, Rao and Rajeswara Rao 2006). Furthermore, socio-cultural and economic characteristics of gardeners are important for explaining plant diversity in homegardens. For example, Howard (2006) showed that in Latin American homegardens, the division of labor, knowledge, access to garden resources, and degree of commoditization help to explain the structure, composition, and functions of homegardens. The sex of the gardener and the gendered distribution of gardening tasks are related to diversity in homegardens in the Iberian Peninsula (Reyes-García et al. 2010), where despite being smaller and closer to the dwelling, gardens managed mainly by women have greater species diversity per unit area compared with those managed mainly by men. In Peruvian Amazonian gardens, differences in homegarden diversity are related to ethnicity (Uranina, mestizos, and Achuar) in terms of species richness, homegarden composition, and the presence of medicinal plants; some medicinal species are exclusively cultivated by one or another ethic group (Perrault-Archambault and Coomes 2008). Finerman and Sackett (2003) have observed that in the Ecuadorian Andes, where gardens are managed by women and are largely devoted to medicinal plant production, species composition reflects household demographics (e.g., age, composition) and stage in the life cycle (e.g., reproductive status), as well as specific health needs of individuals in the household.

Homegarden diversity is also strongly influenced by access to and exchange of planting material, i.e., seeds, stakes, stems, and cuttings (Aguilar-Støen et al. 2009, Coomes 2010), which are critical for developing and maintaining plant diversity. Peoples' movements and migratory patterns are typically accompanied by flows of seeds and plants, which modify, enrich, and diversify migrants' homegardens (Voeks 2004, Kujawska and Pardo-deSantayana 2015). For example, in a study of planting material exchange networks among indigenous peoples in the Peruvian Amazon, Lerch (1999) found a positive association between plant diversity in homegardens and household frequencies of plant exchanges; Ban and Coomes (2004) found similar results in the same region. However, the exchange of homegarden planting

\footnotetext{
${ }^{1}$ Institut de Ciència i Tecnologia Ambientals (ICTA), Universitat Autònoma de Barcelona, ${ }^{2}$ Department of Social Sciences, Wageningen University, ${ }^{3}$ Centre for Biocultural Diversity Studies, University of Kent, ${ }^{4}$ Social and Cultural Anthropology Department, Universitat Autònoma de Barcelona, ${ }^{5}$ Institució Catalana de Recerca i Estudis Avançats (ICREA)
} 
material is usually contained within certain social networks. Most exchanges occur between kin, relatives, close friends, and neighbors (Aguilar-Støen et al. 2009, Buchmann 2009), and predominately between women (Boster 1985, Sereni Murrieta and Winklerprins 2003, Lope-Alzina and Howard 2012).

\section{Navigating social exchange through social network analysis}

Only recently have researchers begun to apply social network analysis to investigate the exchange of homegarden products (goods and planting materials) and related knowledge. CalvetMir et al. (2012) explored the seed exchange network for homegardens in the Catalan Pyrenees and evaluated its contribution to agrobiodiversity conservation. They found that people who were mentioned more often in seed exchange networks and who had a higher level of intermediation conserved more local landraces and had more knowledge of such varieties compared with people who were less central in the network. In a similar study among gardeners in the Iberian Peninsula, ReyesGarcía et al. (2013) found that the number of contacts that an individual had in the germplasm exchange network was positively associated with their agroecological knowledge. Lope-Alzina (2014) reported that, among members of a Yucatec-Maya community in Mexico, homegardens are the main source of exchanged planting material. The author found that despite strong market participation, gift-giving continues to be the predominant form of exchange, with most gifts coming from homegardens and with most exchanges occurring between women in kinship-based networks. Elderly women at the top of the hierarchy within their own kin networks were the most outstanding givers.

Social network analysis has also been used to explore medicinal plant knowledge transmission pathways. For example, Hopkins' (2011) study of Yucatec-Maya in Mexico suggests that an individual's knowledge of herbal medicines is positively associated with that individual's structural position within the herbal remedy network. Other researchers have assessed selective learning biases in cultural transmission pathways through social network modeling. Henrich and Broesch (2011) asked Fijian villagers about who they would approach for advice if they had a question about how to use medicinal plants; their results suggest that being knowledgeable, older, and female, and lacking formal education increase the chances of being selected as a model for learning about medicinal plants. In summary, findings from previous research suggest that the individual structural position in social networks is associated with medicinal plant knowledge, and that kinship, sex, and cultural learning pathways shape social networks.

Here, we seek to contribute to these lines of research by assessing the influence that the exchange of medicinal knowledge and plant material through social networks have for medicinal plant diversity in Tsimane' Amazonian homegardens. We explore whether social organization (i.e., kinship, gender relations, and division of labor and tasks in gardening) patterns the exchange of medicinal plant knowledge and medicinal plant material. We use network centrality measures to evaluate people's location and performance in knowledge and plant material exchange networks, hypothesizing that people with higher centrality in the knowledge or plant material network maintain a higher diversity of medicinal plants in their homegarden.

\section{METHODS}

Our research was carried out among Tsimane' foragerhorticulturalists in the Amazonian lowland forest of Beni Department, Bolivia. We selected two villages located along the Maniqui River, within the Tsimane' Indigenous Territory. Although both villages are relatively isolated and self-sufficient, they differ in their degree of isolation. One village is closer to the market town (it can be reached after a one-day canoe trip) whereas the other is more isolated (it can be reached after a three-day canoe trip; Fig. 1).

Fig. 1. Map of the study area in Amazonian Bolivia.

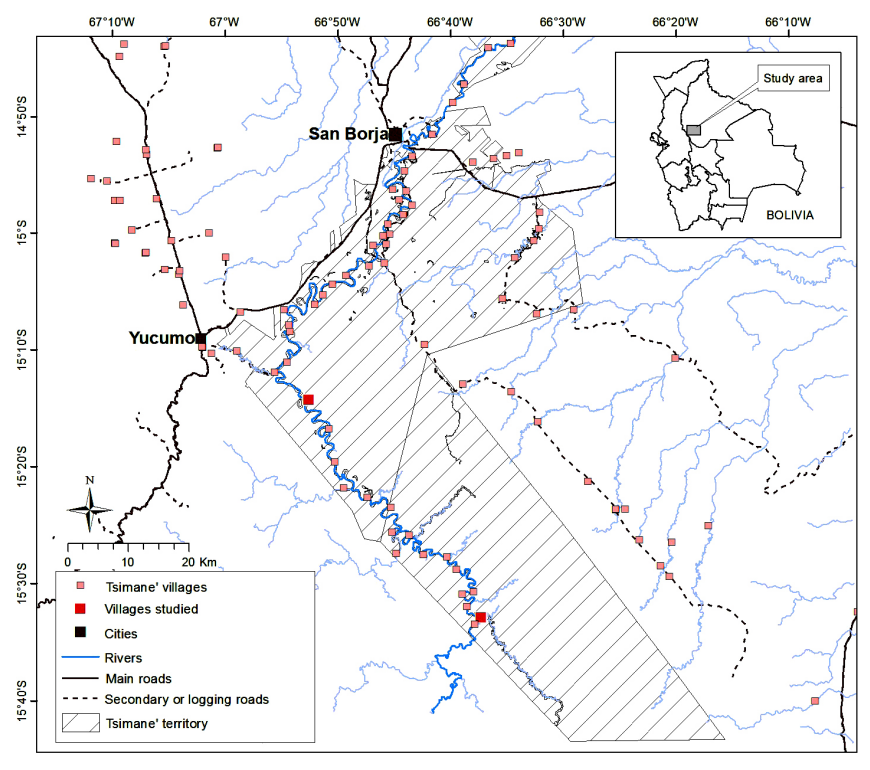

Social organization in Tsimane' villages is largely kinship based, whereby most Tsimane' practice cross-cousin marriage (Daillant 2003), and residence is commonly matrilocal (couples live with or near the wife's parents). Traditionally, the Tsimane's seminomadic settlements were small, consisting of clusters of two to three extended family households that were often considerable distances apart (Chiccón 1992, Ellis 1996). The influence of Protestant missionaries and the introduction of formal education in the mid-20th century fostered the settlement and confluence of different clans or clusters around schools. Today, the Tsimane' still change residence very frequently, even within villages, moving closer to their agricultural plots in the harvest season and to rivers in the dry season, when fish are plentiful.

In these villages, livelihoods are mostly subsistence-oriented and depend on foraging and swidden agriculture. In addition to having swidden plots located at varying distances from the household, the Tsimane' cultivate and manage a diversity of species in homegardens. While there are many and diverse ways to define homegardens (see e.g., Kumar and Nair 2006), we use a concept that coincides well with the type of land use practiced by the Tsimane': "the peridomestic area belonging to the household where members plant and/or tend useful plants" (PerraultArchambault and Coomes 2008). Frequently used or common medicinal plants are found in homegardens together with fruit trees, cotton, and chili pepper (Reyes-García et al. 2003, 2005). 
Because access to biomedical healthcare is very limited, medicinal plants provide the Tsimane' with locally accessible and socioculturally relevant options for treating health complaints. Ailments are firstly treated in the household, where women are the principle healers (Chiccón 1992). However, both women and men cultivate plants in the area around their houses. Quite interestingly, the Tsimane' recognize customary ownership of these medicinal plants and have detailed knowledge of such rights (see also Howard and Nabanoga 2007). In the Tsimane's customary usufruct tenure system, gardens belong to the families who originally established them (e.g., former residents). Abandoned gardens are usually reoccupied by the families that previously abandoned them or by their closest relatives, who obtain permission from the previous occupants to use them (Piland 2000). When a family member dies, to get rid of bad spirits and avoid visits by the deceased's spirit, the Tsimane' move to another location (Chicchón 1992); the garden that remains behind is left intact (Piland 2000).

\section{Data collection}

The first and third authors lived in the area for 18 months (January 2012-November 2013) allowing them to observe actively as well as to participate and interact with the Tsimane' while gardening. Different tasks were performed with some of the informants; for example, we accompanied them while gathering products from their gardens and helped with tasks such as planting and weeding.

Between August and December 2012, individual inventories were made of all plants in homegardens that were planted or managed by household heads. A total of 86 informants were interviewed ( 46 women and $40 \mathrm{men}$ ), which represented approximately $80 \%$ of all household heads. Of these, 55 lived in the village closer to town, and 31 lived in the more isolated village. Each informant was asked individually to show the plants kept in the garden and to provide their vernacular or common names and uses. Uses were classified into four categories: food, medicine, artisanal (including plants used for making bags, carpets, and bows and arrows), and other (including fish poisoning, ornamental, and construction uses). A given plant could fall into more than one category (e.g., a plant with both food and medicinal uses). When the informants indicated a plant with medicinal uses, they were asked about the ailments it was used to treat.

Social network data were compiled through individual interviews. We used recall methods that employed a set of name generators to collect network data in relation to knowledge (e.g., information and advice about medicinal plants) and plant material (propagates, seeds, plants) exchange (hereafter medicinal plant exchange networks; Table 1). The names collected were limited to people who resided within the village, as a boundary for a whole network analytical approach. In addition to data on social relations, we collected demographic data on each informant, including sex, age (in years), kinship relations, years of residence in the village, and years residing in the household. Because some informants in each village were not members of a village clan (e.g., the teacher and his wife, who are Tsimane' from another village but reside in the studied village), they were considered as separate clans for the descriptive analysis (clans 5 and 9) and were excluded from the statistical analysis.
Table 1. Name generating questions used to elicit information on knowledge and medicinal plant material exchange social networks in homegardens in two Tsimane' villages.

\begin{tabular}{c}
\hline \hline Network Question asked (name generator) \\
\hline Medicinal plant knowledge network \\
Q1: Could you tell me the names of anyone who has \\
ever given you advice about medicinal plants? \\
Q2: Could you list the names of people to whom you \\
have ever given advice about medicinal plants? \\
Q3: Could you list the names of people who gave you \\
medicinal plants for your homegarden? \\
Q4: Could you list the names of people to whom you \\
have ever given medicinal plant material or remedies \\
from your homegarden? \\
Q5: While doing the inventory, for each medicinal plant \\
the informants showed us, we asked: Has someone \\
given you this plant? If so, could you tell me the name \\
of the person who gave you this plant?
\end{tabular}

We also assessed the medicinal plant knowledge of garden managers. We first asked 20 men and women from both villages to free-list the medicinal plants they knew so that we could design a knowledge survey that consisted of structured questions regarding 16 medicinal plants that were chosen according to their frequency and position in the free-listing or their "salience" (Thompson and Zhang 2006). We created three salience groups by randomly selecting the three species with the highest or lowest salience and four species with medium salience. Additionally, we analyzed women's and men's free-listings separately and selected three more species that were listed only by women and three listed only by men. During the knowledge survey (available at http:// icta.uab.cat/Etnoecologia/Docs/[423]-lektests.pdf), local assistants read out the vernacular names of the selected medicinal plants, asking gardeners whether they knew the plant and, if so, to list up to three different medicinal uses for that plant. The average number of uses known per known species was used to assess individuals' medicinal plant knowledge.

\section{Analysis}

We used richness as a proxy for diversity in homegardens, i.e., the number of different species inventoried per informant's garden. The richness of plant species in homegardens was measured for each informant using inventory data. Total richness is the number of distinct species (including those with medicinal, food, artisanal, and other uses) inventoried per informant garden. Medicinal plant richness is the number of distinct plant species with medicinal uses inventoried per informant garden.

We recorded the vernacular names given by interviewees (Hanazaki et al. 2000, Perrault-Archambault and Coomes 2008) and then identified their scientific equivalents using previous ethnobotanical studies in the area (see Appendix 1) and assigned codes to calculate richness. For example, the local names seviria and vira' vira' are synonyms that refer to a single botanical species, Cymbopogon citratus, so the same code was assigned to both vernacular names to avoid double counting. When it was not possible to link vernacular names to botanical nomenclature because this information was not available, we assigned unique 
codes to all of the vernacular names given by informants. This might lead to the overestimation of species richness because some of these vernacular names probably refer to the same species. Also, it might have led us to underestimate the actual number of species because a single vernacular name may refer to different species; Cavalcanti and Alburquerque (2013) call this "hidden diversity". We described the overall composition of homegardens by village, clan, sex of the gardener, and age group. To this end, kinship data were used to assign informants to one of nine different clans identified, and informants were also classified into one of four age groups $(\leq 25,26-35,36-45$, and $>45$ years old $)$.

\section{Social network analysis}

Using information on social exchange networks, we built a whole network matrix and calculated a set of graph-based measures (McCarty and Molina 2015) for each village (group level) and informant (individual level). Information was treated as undirectional and analyzed with UCINET6-Netdraw for Windows. Nominations elicited with a multiple name generator approach were aggregated in a single file by village because we considered that planting material often flows together with the associated knowledge; in other words, when people give or receive planting material, they typically also give or receive explanations on how to grow and use the species (Reyes-García et al. 2013). For each village exchange network, we calculated: (1) size, or number of people in the network; (2) density, or the proportion of existing connections in the network relative to the maximum possible number of connections (0-1); (3) centralization, or tendency for a few people to centralize the existing connections (expressed as a percentage); and (4) reciprocity, or the extent of reciprocated ties. We calculated three centrality measures for each person in the network (Freeman 1977, 1979, Wasserman and Faust 1994, Everett and Borgatti 2000): degree, or number of people with whom a person is directly connected; betweenness, or the extent to which a given person (ego) appears in the path connecting other people in the network; and egobetweeness, or the number of people connected to each other only through the ego, a measure that captures the importance of a person in her or his personal network. Data were treated as undirected to capture the existence of a relation regardless of the direction of the nomination.

We calculated an external-internal index (E-I index; Krackhardt and Stern 1988) to explore the effect of clan membership, sex, and age of the gardener on exchanges of knowledge and plant material. The E-I index is proposed as:

$$
E-I \text { index }=\frac{E L-I L}{E L+I L}
$$

where EL is the number of external exchanges of medicinal knowledge and plant material, and EI is the number of internal exchanges of medicinal knowledge and plant material.

Therefore, given the partition of a network into a number of mutually exclusive groups (here, clans, sex, or age groups), the EI index evaluates the relation between external and internal exchanges, i.e., relative homophily, or people's tendency to relate to others who are similar to themselves, leading to preferential exchanges within groups. The E-I index ranges from -1 (all ties are within the group) to +1 (all ties are external to the group). EI index $=0$ when a group has the same number of internal and external ties. A permutation test $(N=5000)$ was performed to assess whether the network E-I index was significantly different than expected.

\section{Statistical analysis}

To estimate the association between medicinal plant richness managed by an informant and informants' centrality measures, we ran a Poisson multivariate regression, which is adequate for count data. We first tested whether degree centrality was associated with medicinal plant richness while controling for additional factors that research suggests affect diversity in the homegarden. Specifically, controls in our regression included: village or residence, clan membership, sex, age (in years), and age squared (Age2; to control for nonlinearity in the relation between age and medicinal knowledge, as cognitive ability might decrease among elders), years of residence in the village (to control for mobility), years residing in the same house (as a proxy for homegarden age), and individuals' medicinal plant knowledge. We used STATA 13 for Mac for the statistical analysis.

\section{RESULTS}

\section{Richness in Tsimane' homegardens}

A total of 111 plants were inventoried, of which 45 were used as medicines. The total richness in gardens in the two villages was relatively high and evenly distributed, with 86 and 83 plants encountered in the less isolated and more isolated villages, respectively. Food was the most common use reported, followed by medicinal, artisanal, and other uses. On average, a resident of the less isolated village maintained $11.58(\mathrm{SD}=8.53)$ plants, including $1.90(\mathrm{SD}=2.27)$ with medicinal uses. In the more isolated village, an informant on average maintained $13.67(\mathrm{SD}=7.49)$ plants, 3.54 $(\mathrm{SD}=2.87)$ of those with medicinal uses (Fig. 2).

Fig. 2. Richness of plants in different use categories inventoried by village, clan, and sex-age groups. (A) Less isolated village. (B) More isolated village. (C) Clans 1 to 5 from the less isolated village, clans 6 to 9 from the more isolated village. (D) Sex-age group, with women on left and men on right.

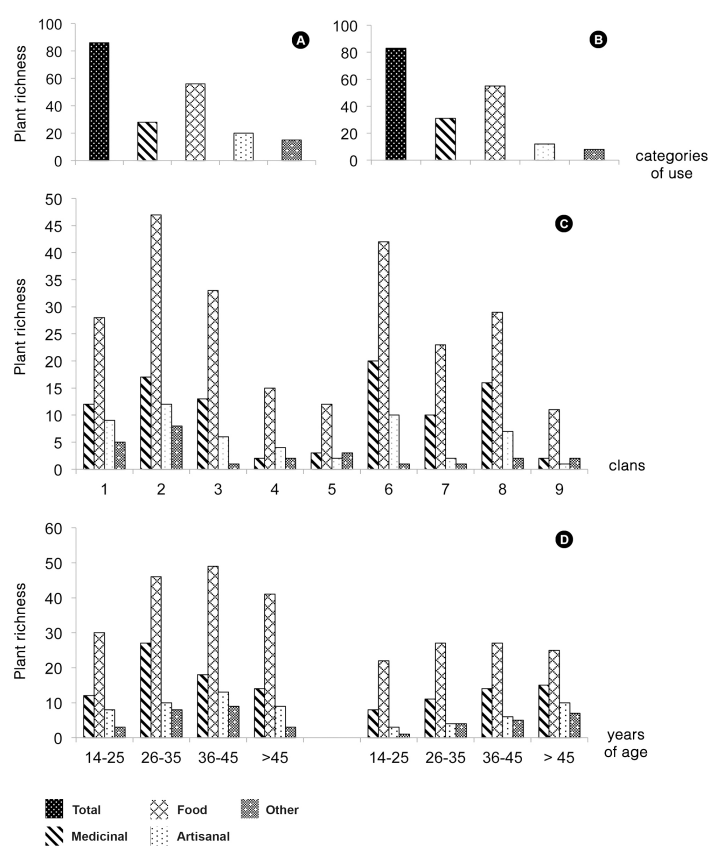


In the less isolated village, women maintained $2.75(\mathrm{SD}=2.58)$ and men $0.96(\mathrm{SD}=1.39)$ medicinal plants. One woman had 12 medicinal plants in her homegarden, but 17 informants $(30.90 \%)$ had none, 12 of whom were men. A similar pattern was found in the more isolated village, where women also maintained more medicinal plants in homegardens $(4.29 ; \mathrm{SD}=3.07)$ compared with men $(2.64 ; \mathrm{SD}=2.37)$, and five informants had none $(16 \%)$, three of whom were men (Fig. 2).

The species most frequently found in homegardens were citruses such as orange (Citrus sinensis) and grapefruit (Citrus paradisi), along with peach palm (Bactris gasipaes), mango (Magnifera indica), and cotton (Gosipyum barbadense). Cotton was almost exclusively planted by women. The medicinal plants most frequently found in homegardens were ginger (Zingiber officinale), tobacco (Nicotina tabacum), and garlic weed (Petiveria alliacea). Of the total number of times that medicine was reported as a use, $15 \%$ were used for treating common flu, 10\% for general pain, $10 \%$ for fungal infections of the skin, and $5 \%$ each for diarrhea and stomach afflictions, injuries, wasp stings, and skin parasites.

\section{Structure of medicinal knowledge and plant material exchange networks}

There were 48 gardeners involved in medicinal plant exchange networks in the less isolated village and 37 in the more isolated village (Fig. 3). These networks were characterized by low density ( 0.034 vs. 0.063 , less isolated vs. more isolated village), low centralization indexes $(8.08 \%$ vs. $6.28 \%$ ), and low reciprocity ( 0.0317 vs. 0.109$)$, meaning that connections in the networks are relatively low and not reciprocal. Overall, both networks show asymmetry and hierarchy, meaning that some people have many more connections than others.

Fig. 3. Medicinal plant exchange networks (undirected) by village. (A) Less isolated village. (B) More isolated village. Purple nodes, women; green nodes, men; node size indicates degree centrality.

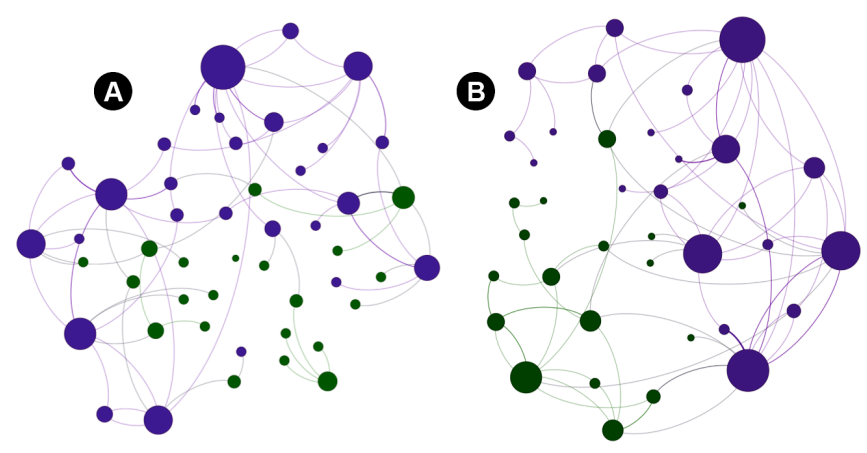

We found different patterns in the exchanges of medicinal knowledge and plant material between E-I indexes calculated by clan membership and sex, but not by age group (Fig. 4). When grouped by clan membership, larger clans $(2,3$, and 8$)$ tended to have more exchanges within the same clan, whereas smaller clans $(1,4,6$, and 7$)$ had mostly external exchanges. The permutation tests revealed statistically significant differences for the E-I index between clans for the less isolated village $(P<0.05)$, meaning that different clans had dissimilar exchange patterns. Sex groups presented homophily, with most exchanges occurring within the same-sex group; this difference was significant for both villages $(P<0.05)$. Most exchanges occurred between age groups, and differences among E-I indexes within age groups were not statistically significant.

Fig. 4. Graphic representation of external-internal (E-I) indexes by clan (A, B), sex (C, D), and age-group (E, F). (A, C, E) Less isolated village. $(\mathrm{B}, \mathrm{D}, \mathrm{F})$ More isolated village. $\mathrm{E}-\mathrm{I}$ index evaluates the relationship between external and internal exchanges, ranging from -1 (all ties within the group) to +1 (all ties external to the group); if the ties are divided equally, the index is zero.
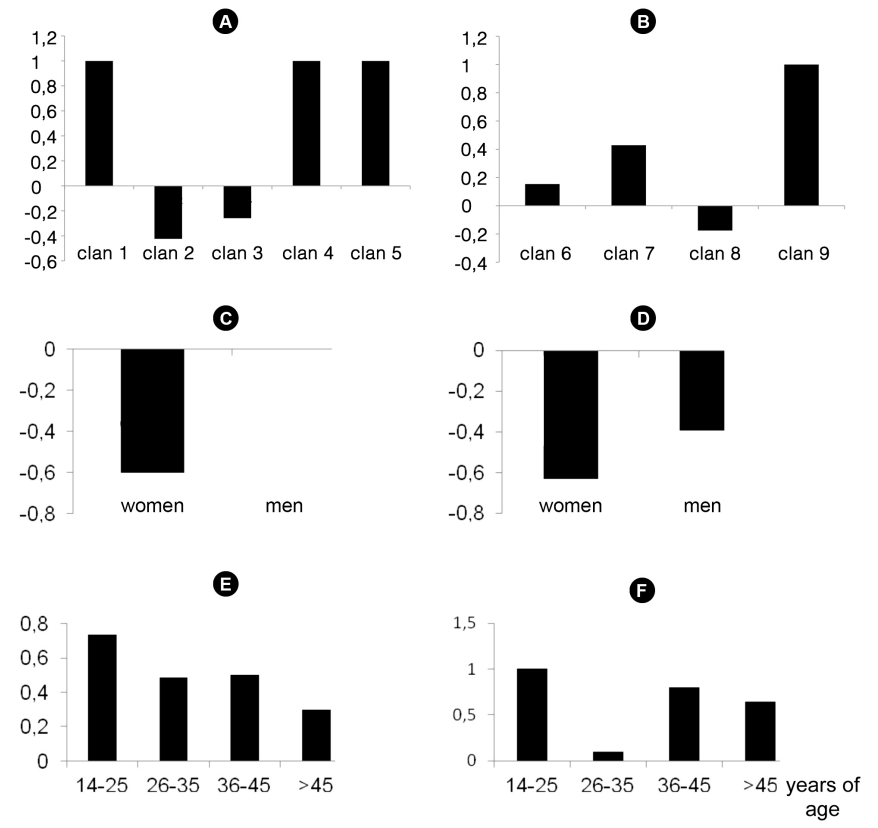

\section{Centrality measures}

On average, centrality measures were higher in the more isolated village and for women. The average degree values were 2.96 (SD $=2.90)$ and $4.17(\mathrm{SD}=2.48)$ for women in the less and more isolated villages, respectively, and $1.15(\mathrm{SD}=1.36)$ and $3.35(\mathrm{SD}$ $=3.12$ ) for men, respectively, indicating that women exchanged (gave or received) medicinal plants with more people than did men (Fig. 3). The average value for betweenness centrality followed a similar pattern, with women in both villages having a similar value $($ mean $=80.70, \mathrm{SD}=127.56$ in the less isolated village; mean $=81.59, \mathrm{SD}=76.50$ in the more isolated village), meaning that on average, each woman connected 80 pairs of otherwise unconnected informants. There was high variation in this variable, indicating that some women had a much more pronounced centralizing role in the network than did others. Average betweenness values were lower for men (less isolated village 27.30, $\mathrm{SD}=56.99$; more isolated $39.84, \mathrm{SD}=184.02$ ). Betweenness displayed greater variation for men than for women, suggesting greater variation in men's bridging role, particularly in the more isolated village. Similarly, the average value of the 
Table 2. Definition and descriptive statistics for variables used in the multivariate analysis.

\begin{tabular}{|c|c|c|c|c|c|c|}
\hline Variable & Definition & $N$ & Mean & $\mathrm{SD}$ & Min. & Max. \\
\hline \multicolumn{7}{|l|}{ Outcome variables } \\
\hline Medicinal richness & $\begin{array}{l}\text { Total number of medicinal plant species } \\
\text { inventoried by informant homegarden }\end{array}$ & 86 & 2.5 & 2.61 & 0 & 12 \\
\hline Total richness & $\begin{array}{l}\text { Total number of plant species inventoried by } \\
\text { informant homegarden }\end{array}$ & 86 & 12.3 & 8.19 & 2 & 39 \\
\hline \multicolumn{7}{|l|}{ Explanatory variables } \\
\hline Degree & $\begin{array}{l}\text { Number of people with whom a person is directly } \\
\text { connected }\end{array}$ & 86 & 4.2 & 2.83 & 1 & 11 \\
\hline Betweenness & $\begin{array}{l}\text { Grade of intermediation among people where } \\
\text { each person is directly and indirectly connected }\end{array}$ & 86 & 94.0 & 112.0 & 0 & 586 \\
\hline Egobetwenness & $\begin{array}{l}\text { Grade of intermediation among people where } \\
\text { each person is directly connected }\end{array}$ & 86 & 8.9 & 11.7 & 0 & 50 \\
\hline \multicolumn{7}{|c|}{ 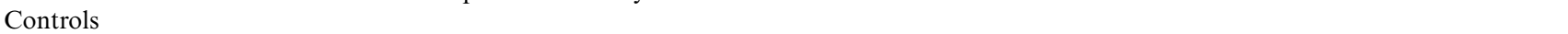 } \\
\hline Age & Age of the person (yr) & 85 & 39.3 & 16.6 & 14 & 88 \\
\hline $\mathrm{Age}^{2}$ & $\begin{array}{l}\text { Age-squared term to control for nonlinearity in } \\
\text { the relation between age and richness in } \\
\text { homegardens }\end{array}$ & 85 & 1815 & 1687.4 & 196 & 7744 \\
\hline Medicinal knowledge & $\begin{array}{l}\text { Average number of medicinal uses known per } \\
\text { plant known from a knowledge survey of } 16 \\
\text { medicinal plants }\end{array}$ & 80 & 0.87 & 0.41 & 0.13 & 2 \\
\hline Years in household & $\begin{array}{l}\text { Number of years a person resided in the in the } \\
\text { same household }\end{array}$ & 81 & 6.7 & 7.1 & 0.1 & 25 \\
\hline Years in village & $\begin{array}{l}\text { Number of years that the person resided in the } \\
\text { village }\end{array}$ & 79 & 23.2 & 13.5 & 1 & 66 \\
\hline \multirow[t]{2}{*}{ Less isolated village } & Village of residence closer to town & 55 & & & & \\
\hline & More isolated village & 31 & & & & \\
\hline \multirow[t]{10}{*}{ Clan } & Clan membership & & & & & \\
\hline & 1 & 8 & $9.30^{\dagger}$ & & & \\
\hline & 2 & 17 & $19.77^{\dagger}$ & & & \\
\hline & 3 & 22 & $25.58^{\dagger}$ & & & \\
\hline & 4 & 6 & $6.98^{\dagger}$ & & & \\
\hline & 5 & 2 & $2.33^{\dagger}$ & & & \\
\hline & 6 & 11 & $12.79^{\dagger}$ & & & \\
\hline & 7 & 7 & $8.14^{\dagger}$ & & & \\
\hline & 8 & 11 & $12.79^{\dagger}$ & & & \\
\hline & 9 & 2 & $2.33^{\dagger}$ & & & \\
\hline \multirow[t]{3}{*}{ Male } & $\begin{array}{l}\text { Dummy variable capturing the sex of the } \\
\text { informant, }(1=\text { male, } 0=\text { female })\end{array}$ & & & & & \\
\hline & Female & 46 & $53.49^{\dagger}$ & & & \\
\hline & Male & 40 & $46.51^{\dagger}$ & & & \\
\hline
\end{tabular}

variable egobetweenness was considerably higher for women (less isolated village $5.78, \mathrm{SD}=10.98$; more isolated village 8.17 , $\mathrm{SD}$ $=9.59$ ) compared with men (less isolated $0.82, \mathrm{SD}=1.94$; more isolated 6.71, $\mathrm{SD}=12.38$ ), although again, men's egobetweenness displayed greater variation than women's.

\section{Medicinal plant richness in homegardens and centrality in the exchange network}

We analyzed the link between informants' medicinal richness in homegardens and informants' locations in the medicinal plant exchange networks (assessed through centrality measures; see Table 2). Degree centrality, which measures the number of people with whom a person is directly connected, had a statistically significant relation with medicinal richness in homegardens. The association was robust for all regressions. Across all models, the variable "male" displayed a greater and more consistent association with medicinal plant richness, suggesting that women have a prominent role in these networks.
In model A, we tested the association between a person's degree centrality and the richness of medicinal plant species that they maintain in their homegarden, controlling for village, sex, and age (Table 3). Results indicate that a person's degree centrality had a positive and statistically significant association with medicinal plant richness (coefficient $=0.122, P<0.0001$ ). In other words, the higher the number of connections that a person has in the exchange networks, the higher the richness of medicinal plants the person maintains in her or his homegarden. The statistical significance of the less-isolated village dummy variable (coeff. = $0.454, P=0.004$ ) denotes that informants in the less isolated village have higher medicinal plant richness compared with informants in the more isolated village. Results also indicate that women have higher homegarden medicinal plant richness than men (coeff. $=-0.621, P<0.0001$ ), and that people with greater medicinal plant knowledge (coeff. $=0.502, P=0.008$ ) tend to maintain greater medicinal species richness in their homegardens. Age, however, was not significantly associated with homegarden medicinal richness. 
Table 3. Poisson multivariable regressions between informants' medicinal plant richness in homegardens and individual centrality measures. Robust standard errors are given in parentheses. Model C (bold) was used in robustness analysis. See Table 2 for variable definitions.

\begin{tabular}{|c|c|c|c|c|}
\hline Medicinal plant richness model & A & $\mathrm{B}$ & $\mathbf{C}$ & $\mathrm{D}$ \\
\hline Number of observations & 80 & 80 & 76 & 74 \\
\hline \multicolumn{5}{|l|}{ Explanatory variable } \\
\hline Degree & $0.122(0.024)^{* *}$ & $0.127(0.026)^{* *}$ & $0.126(0.025)^{* *}$ & $0.136(0.030)^{* *}$ \\
\hline \multicolumn{5}{|l|}{ Control variables } \\
\hline Less isolated village & $0.454(0.156)^{* *}$ & $\ddagger$ & $\ddagger$ & $\ddagger$ \\
\hline \multicolumn{5}{|l|}{ Clan (omitted clan 6) } \\
\hline 1 & $\ddagger$ & $0.187(0.326)$ & $-0.234(0.353)$ & $0.035(0.340)$ \\
\hline 2 & $\ddagger$ & $-0.068(0.214)$ & $-0.195(0.216)$ & $-0.424(0.265)$ \\
\hline 3 & $\ddagger$ & $-0.447(0.240)^{\dagger}$ & $-0.075(0.245)^{* *}$ & $-0.637(0.256)^{*}$ \\
\hline 4 & $\ddagger$ & $-1.012(0.533)^{\dagger}$ & $-1.107(0.534)^{*}$ & $-0.956(0.538)^{\dagger}$ \\
\hline 7 & $\ddagger$ & $0.389(0.208)^{\dagger}$ & $0.095(0.240)$ & $0.225(0.213)$ \\
\hline 8 & $\ddagger$ & $-0.011(0.313)$ & $-0.295(0.376)$ & $-0.252(0.317)$ \\
\hline Male & $-0.621(0.160)^{* *}$ & $-0.626(0.161)^{* *}$ & $-0.641(0.168)^{* * *}$ & $-0.472(0.168)^{* *}$ \\
\hline Age & $0.029(0.022)$ & $0.029(0.023)$ & $\ddagger$ & 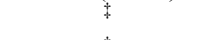 \\
\hline $\mathrm{Age}^{2}$ & $-0.000(0.000)$ & $-0.000(0.000)$ & $\ddagger$ & $\ddagger$ \\
\hline Medicinal knowledge & $0.502(0.188)^{* *}$ & $0.390(0.203)^{\dagger}$ & $0.290(0.204)$ & $0.079(0.221)$ \\
\hline Years in household & 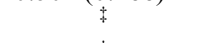 & 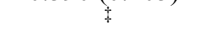 & $0.032(0.011)^{* *}$ & क \\
\hline Years in village & $\ddagger$ & $\star$ & 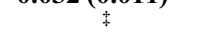 & $0.015(0.005)^{* *}$ \\
\hline$R^{2}$ & 0.22 & 0.25 & 0.25 & 0.25 \\
\hline
\end{tabular}

Model B resembles model A, except that instead of village, we used a set of dummy variables to control for clan membership. As in the previous model, we found that degree centrality was associated with greater medicinal richness in homegardens (coeff. $=0.127, P<0.0001$ ). Compared with people in clan 6 , people in clans $2,3,4$, and 8 had less homegarden medicinal plant richness, and people in clans 1 and 7 had more (see Table 3).

In model $\mathrm{C}$, we excluded the variables age and age $^{2}$ (not significant in previous models) and added the number of years a person has resided in the household. As in the two previous models, we found that degree centrality was associated with higher medicinal plant richness (coeff. $=0.126, P<0.0001$ ). In this model, the variable "male" (coeff. $=-0.641, P<0.0001$ ) and years residing in the household (coeff. $=0.032, P=0.003$ ) were associated with medicinal plant richness, which suggests that women who have had gardens for longer periods also have more medicinal plants in their gardens.

In our final model D, we controled for years residing in the village. Again, we found a positive and statistically significant association between degree centrality and richness (coeff. $=0.136, P<$ $0.0001)$. As in previous models, male was also significantly associated with richness, as was years residing in the village, meaning that people who have longer residency in the same village maintain more medicinal plant richness in their homegardens.

We tested the robustness of the findings by running a set of variations of our best model (Table 3 , model C; $R^{2}=0.25$ ). In our two first robustness tests (see Table 4, models a and b), we changed the explanatory variable using betweenness centrality and egobetweenness instead of degree centrality. In the third robustness model (c), we changed the outcome variable to total richness and kept the same controls as in model $\mathrm{C}$. The last robustness model (d) explored the possible effect of having censoring in the data (18 people did not have any medicinal plants) by fitting a Tobit multivariate regression rather than a Poisson multivariate regression model. Results from the robustness analysis confirm that other centrality measures are also associated with medicinal plant richness. Robustness analysis also suggests that degree centrality has a positive association with total richness in homegardens (coeff. $=0.092, P<0.0001$ ). Finally, the association between degree centrality and richness was also maintained when running a Tobit multivariate regression model (coeff. $=0.457, P<0.0001$ ). In summary, results suggest that the associations found in Table 3 are robust to changes in the specification model.

\section{DISCUSSION}

In this work, we aimed to assess the influence that medicinal plant exchanges through social networks have for homegarden medicinal plant richness by applying social network analysis methods. Our results suggest that Tsimane' social organization, specifically kinship and gender relations, influences exchange patterns significantly. Our findings also show that people who are more central in the network (i.e., who hold higher centrality measures) maintained greater medicinal plant richness, as well as total richness, in their homegardens. Women also maintained a higher richness of medicinal plants in their homegardens than did men.

Previous studies suggest that social organization shapes the pattern of social exchanges in small-scale societies affecting, for example, crop diversity (Leclerc and Coppens d'Eeckenbrugge 2012, Labeyrie et al. 2014) and local ecological knowledge (Salpeteur et al. 2015). Researchers have also argued that planting material exchanges are by no means free-flowing (Coomes and Ban 2004), but rather, are usually confined to kinship networks 
Table 4. Robustness analysis based on variations of model C. Robust standard errors are given in parentheses. See Table 2 for variable definitions and Table 3 for model $\mathrm{C}$.

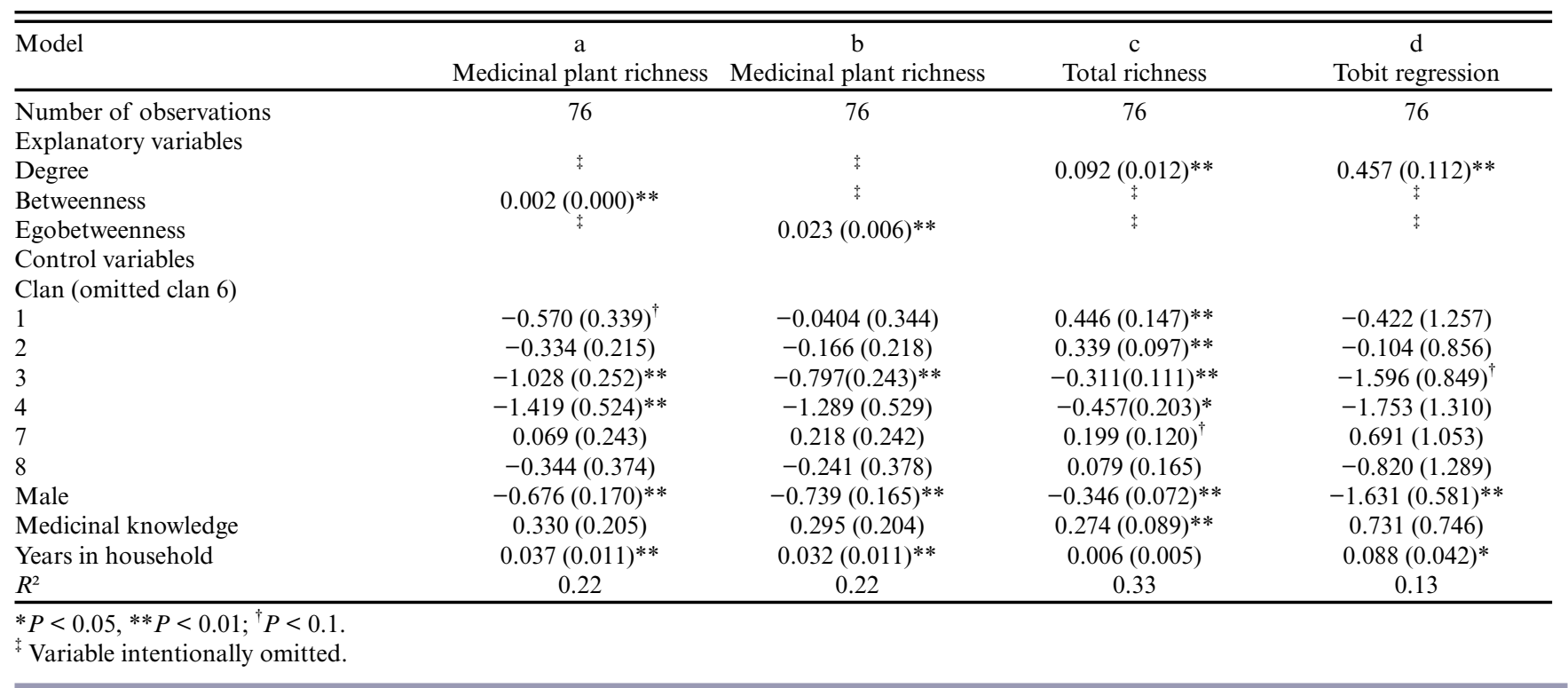

(Aguilar-Støen et al. 2009, Buchmann 2009) in which women often have a prominent role (Boster 1985, Sereni Murrieta and Winklerprins 2003). As has been shown elsewhere (Coomes and Ban 2004), it is possible that this pattern also increases the opportunities to access new planting material for homegardens. For example, among the Achuar in the Peruvian Amazon, planting material such as seeds or cuttings moves mostly through matrilineal kin networks, particularly from female to female (Perrault-Archambault and Coomes 2008). For the Achuar, gardening is traditionally a woman's responsibility and, as in other Amazonian societies, high agrobiodiversity in gardens confers prestige to its owners (Descola 1986 as cited in PerraultArchambault and Coomes 2008).

Our results support these previous studies, showing that exchange of knowledge and plant materials among the Tsimane' are not random, but embedded within networks based on kinship and gender relations. Results suggest that networks are gendered, presenting homophily, where female performance is prominent. Tsimane' social organization can help to explain our findings. It is mostly based on kinship, and within a village, extended families' households are clustered spatially. Socializing among the Tsimane' consists of visits, which are an essential means to maintain close relations. Visiting usually occurs between samesex kin and affines (Ellis 1996), which would facilitate exchanges among members of the same sex and clan, and also explain why it is that larger kin groups tend to have more exchanges. Tsimane' women are considered the main health custodians and are responsible for meeting the primary health needs of their families (Chiccón 1992). Gardening also seems to be primarily a woman's domain, a productive role that is related to their duties as caregivers in the domestic sphere. Women are prominent garden managers across the Latin American region (see Howard 2006 for a review), which is also related to the maintenance of traditional communal social relations, community food security, and health
(Finerman and Sackett 2003, Lope-Alzina and Howard 2012). Homegardening provides women with an opportunity to engage in subsistence production that does not violate gendered norms about men's privileges in the productive sphere (e.g., as principal providers) or about women's domesticity, offering women sources of authority, autonomy, and status, and a place where they can develop specialized knowledge and provide visible means of recognition according to their cultural roles (Howard 2006, LopeAlzina and Howard 2012). Homegardens are also considered as arenas for sociality and experimentation and are a source of pride and self-esteem for women (Heckler 2004). The Tsimane' do not seem to deviate from this pattern.

Locations in a social network provide both possibilities and constraints for accessing resources and knowledge through other people in the network (Calvet-Mir et al. 2012, Kawa et al. 2013) given that in each particular situation, networks can either support or constrain access to these people. Access to other people's planting material is important for developing and maintaining diversity in homegardens (Coomes 2010). In this study, network centrality seems to be associated with a person's performance in medicinal plant exchange networks, as people with higher centrality in the network also maintain higher medicinal plant richness in their homegardens. Compared with men, women are more central in the exchange networks, a finding that fits well with women's prominent role as main garden managers. The gendered networks in which women have higher centrality measures may indicate that they have more access to medicinal planting material and associated knowledge. Other factors such as the number of years that a garden has been tended by its owner and the number of years that a person has resided in the same village also explain medicinal plant richness in Tsimane' homegardens.

We acknowledge the potential shortcomings of our interpretations; our data capture only a snapshot of network 
structure at a single point in time, which, to be valid, assumes that network structures are stable (Howison et al. 2011). Data were also limited in that they were only collected on exchanges that occurred within the same village; exchanges with Tsimane' residing in other villages were not considered, nor were exchanges with non-Tsimane' (i.e., with merchants and researchers). This limits the breadth and explanatory power of our results because social networks are dynamic and embedded within networks at higher local and regional scales.

\section{CONCLUSION}

Our research suggests that social network analysis is an appropriate and useful tool for tracing the uneven flow of homegarden medicinal planting material and knowledge among the Tsimane'. Homegarden medicinal plant richness and total plant species richness are related to gardeners' centrality in the exchange networks, meaning that people with greater centrality maintain greater species richness. Because women generally hold higher centrality, they also maintain greater species richness than do men. Similarly, the number of years the garden has been tended and the number of years a person has resided in the same village are positively related with greater medicinal plant and total plant species richness. In addition, social organization, specifically around kinship and gender, notably influence medicinal plant knowledge and planting material exchange patterns, highlighting that together with agroecological conditions, social relations among gardeners and the culturally specific social structure are important determinants of plant species diversity in homegardens. This suggests that agrodiversity and culture are closely interrelated (Howard 2006, Leclerc and Coppens d'Eeckenbrugge 2012).

Understanding which factors pattern general species diversity in tropical homegardens, and medicinal plant diversity in particular, can help policy makers, health providers, and local communities to understand better how to promote and preserve medicinal plants in situ, so that they can continue to provide locally accessible, culturally appropriate, and economically affordable healthcare options for people with scarce access to biomedical healthcare systems. Such understandings promote the use of gender-sensitive biocultural approaches that offer a culturally appropriate means to reduce the global and local loss of both biological and cultural diversity.

Responses to this article can be read online at: http://www.ecologyandsociety.org/issues/responses. $\mathrm{php} / 7944$

\section{Acknowledgments:}

This research was funded by the European Research Council under the European Union's Seventh Framework Programme (FP7/2007-2013)/ERC grant agreement FP7-261971-LEK to Reyes-Garcia. We are grateful to all of our informants for their willingness to share their time and knowledge, and for kindly showing us their homegardens. We also thank the Gran Consejo Tsimane' and the CBIDSI for providing logistical support and office facilities in San Borja; and we thank Marta Pache, Paulino Pache, Vicente Cuata, Sascha Huditz, and Giuliana Castañeda for field assistance, as well as Maximilien Guèze for assistance with mapping. We are very grateful to two anonymous reviewers for their thoughtful suggestions.

\section{LITERATURE CITED}

Aceituno-Mata, L. 2010. Estudio etnobotánico y agroecológico de la Sierra Norte de Madrid. Dissertation. Universidad Autónoma de Madrid, Madrid, Spain. [online] URL: http://bibdigital.rjb. csic.es/PDF/Aceituno_Estud_Etnobot_Sierra_N_Madrid 2010. pdf.

Aguilar-Støen, M., S. R. Moe, and S. L. Camargo-Ricalde. 2009. Home gardens sustain crop diversity and improve farm resilience in Candelaria Loxicha, Oaxaca, Mexico. Human Ecology 37 (1):55-77. http://dx.doi.org/10.1007/s10745-008-9197-y

Ban, N., and O. T. Coomes. 2004. Home gardens in Amazonian Peru: diversity and exchange of planting material. Geographical Review 94(3):348-367. http://dx.doi.org/10.1111/j.1931-0846.2004. tb00177.x

Bernholt, H., K. Kehlenbeck, J. Gebauer, and A. Buerkert. 2009. Plant species richness and diversity in urban and peri-urban gardens of Niamey, Niger. Agroforestry Systems 77(3):159-179. http://dx.doi.org/10.1007/s10457-009-9236-8

Boster, J. S. 1985. Requiem for the omniscient informant: there's life in the old girl yet. Pages 177-198 in J. W. D. Dougherty, editor. Directions in cognitive anthropology. University of Illinois Press, Champaign, Illinois, USA.

Buchmann, C. 2009. Cuban home gardens and their role in socialecological resilience. Human Ecology 37(8):705-721. http://dx.doi. org/10.1007/s10745-009-9283-9

Calvet-Mir, L., M. Calvet-Mir, J. L. Molina, and V. Reyes-García. 2012. Seed exchange as an agrobiodiversity conservation mechanism. A case study in Vall Fosca, Catalan Pyrenees, Iberian Peninsula. Ecology and Society 17(1):29. http://dx.doi. org/10.5751/es-04682-170129

Cavalcanti, D. R., and U. P. Albuquerque. 2013. The "hidden diversity" of medicinal plants in northeastern Brazil: diagnosis and prospects for conservation and biological prospecting. Evidence-based Complementary and Alternative Medicine 2013: 102714. http://dx.doi.org/10.1155/2013/102714

Chicchón, A. 1992. Chimane resource use and market involvement in the Beni Biosphere Reserve, Bolivia. Dissertation. University of Florida, Gainesville, Florida, USA. [online] URL: http://ufdc.ufl. edu/AA00003266/00001.

Coomes, O. T. 2010. Of stakes, stems, and cuttings: the importance of local seed systems in traditional Amazonian societies. Professional Geographer 62(3):323-334. http://dx.doi. org/10.1080/00330124.2010.483628

Coomes, O. T., and N. Ban. 2004. Cultivated plant species diversity in home gardens of an Amazonian peasant village in northeastern Peru. Economic Botany 58(3):420-434. http://dx.doi. org/10.1663/0013-0001(2004)058[0420:CPSDIH]2.0.CO;2

Daillant, I. 2003. Sens dessus dessous: organisation sociale et spatiale des Chimane d'Amazonie bolivienne. Recherches amèricaines 6. Société d'ethnologie, Nanterre, France. 
Ellis, R. 1996. A taste for movement: an exploration of the social ethics of the Tsimane' of lowland Bolivia. Dissertation. University of St. Andrews, St. Andrews, UK. [online] URL: http://hdl. handle.net/10023/2901.

Everett, M., and S. P. Borgatti. 2005. Ego network betweenness. Social Networks 27(1):31-38. http://dx.doi.org/10.1016/j. socnet.2004.11.007

Finerman, R., and R. Sackett. 2003. Using home gardens to decipher health and healing in the Andes. Medical Anthropology Quarterly 17(4):459-482. http://dx.doi.org/10.1525/maq.2003.17.4.459

Freeman, L. C. 1977. A set of measures of centrality based on betweenness. Sociometry 40(1):35-41. http://dx.doi.org/10.2307/3033543

Freeman, L. C. 1979. Centrality in social networks: conceptual clarification. Social Networks 1(3):215-239. http://dx.doi. org/10.1016/0378-8733(78)90021-7

Hanazaki, N., J. Y. Tamashiro, H. F. Leitão-Filho, and A. Begossi. 2000. Diversity of plant uses in two Caiçara communities from the Atlantic Forest coast, Brazil. Biodiversity and Conservation 9 (5):597-615. http://dx.doi.org/10.1023/A:1008920301824

Heckler, S. L. 2004. Cultivating sociality: aesthetic factors in the composition and function of Piaroa homegardens. Journal of Ethnobiology 24(2):203-232.

Henrich, J., and J. Broesch. 2011. On the nature of cultural transmission networks: evidence from Fijian villages for adaptive learning biases. Philosophical Transactions of the Royal Society $B$ 366(1577):1139-1148. http://dx.doi.org/10.1098/rstb.2010.0323

Hopkins, A. 2011. Use of network centrality measures to explain individual levels of herbal remedy cultural competence among the Yucatec Maya in Tabi, Mexico. Field Methods 23(3):307-328. http://dx.doi.org/10.1177/1525822x11399400

Howard, P. L. 2006. Gender and social dynamics in swidden and homegardens in Latin America. Pages 159-182 in B. M. Kumar and P. K. R. Nair, editors. Tropical homegardens: a time-tested example of sustainable agroforestry. Springer, Dordrecht, The Netherlands. http://dx.doi.org/10.1007/978-1-4020-4948-4 10

Howard, P. L., and G. Nabanoga. 2007. Are there customary rights to plants? An inquiry among the Baganda (Uganda), with special attention to gender. World Development 35(9):1542-1563. http://dx.doi.org/10.1016/j.worlddev.2006.05.021

Howison, J., A. Wiggings, and K. Crowston. 2011. Validity issues in the use of social network analysis with digital trace data. Journal of the Association for Information Systems 12 (12):767-797.

Huai, H., and A. Hamilton. 2009. Characteristics and functions of traditional homegardens: a review. Frontiers of Biology in China 4(2):151-157. http://dx.doi.org/10.1007/s11515-008-0103-1

Kawa, N. C., C. McCarty, and C. R. Clement. 2013. Manioc varietal diversity, social networks, and distribution constraints in rural Amazonia. Current Anthropology 54(6):764-770. http://dx. doi.org/10.1086/673528

Kehlenbeck, K., and B. L. Maass. 2004. Crop diversity and classification of homegardens in Central Sulawesi, Indonesia. Agroforestry Systems 63(1):53-62. http://dx.doi.org/10.1023/b: agfo.0000049433.95038.25
Krackhardt, D., and R. N. Stern. 1988. Informal networks and organizational crises: an experimental simulation. Social Psychology Quarterly 51(2):123-140. http://dx.doi.org/10.2307/2786835

Kujawska, M., and M. Pardo-de-Santayana. 2015. Management of medicinally useful plants by European migrants in South America. Journal of Ethnopharmacology 172:347-355. http://dx. doi.org/10.1016/j.jep.2015.06.037

Kumar, B. M., and P. K. R. Nair, editors. 2006. Tropical homegardens: a time-tested example of sustainable agroforestry. Springer, Dordrecht, The Netherlands. http://dx.doi. org/10.1007/978-1-4020-4948-4

Labeyrie, V., B. Rono, and C. Leclerc. 2014. How social organization shapes crop diversity: an ecological anthropology approach among Tharaka farmers of Mount Kenya. Agriculture and Human Values 31(1):97-107. http://dx.doi.org/10.1007/ s10460-013-9451-9

Leclerc, C., and G. Coppens d'Eeckenbrugge. 2012. Social organization of crop genetic diversity. The $\mathrm{G} \times \mathrm{E} \times \mathrm{S}$ interaction model. Diversity 4(1):1-32. http://dx.doi.org/10.3390/d4010001

Lerch, N. C. 1999. Home gardens, cultivated plant diversity, and exchange of planting material in the Pacaya-Samira National Reserve Area, northeastern Peruvian Amazon. Thesis. McGill University, Montreal, Canada.

Lope-Alzina, D. G. 2014. Una red comunal de acceso a alimentos: el huerto familiar como principal proveedor de productos para intercambio en una comunidad Maya-Yucateca. Gaia Scientia Volume Especial Populações Tradicionais:199-215. [online] URL: http://periodicos.ufpb.br/ojs/index.php/gaia/article/ view/22430/12539.

Lope-Alzina, D. G., and P. L. Howard. 2012. The structure, composition, and functions of homegardens: focus on the Yucatán Peninsula. Etnoecológica 9(1):17-41.

McCarty, C., and J. L. Molina. 2015. Social network analysis. Pages 631-657 in H. R. Bernard and C. G. Gravlee, editors. Handbook of methods in cultural anthropology. Second edition. Rowman and Littlefield, Lanham, Maryland, USA.

Perrault-Archambault, M. and O. T. Coomes. 2008. Distribution of agrobiodiversity in home gardens along the Corrientes River, Peruvian Amazon. Economic Botany 62(2):109-126. http://dx.doi. org/10.1007/s12231-008-9010-2

Piland, R. 2000. Agricultura Tsimane' y su relación con la conservación en la Reserva de la Biosfera Estación Biológica del Beni, Bolivia. Pages 329-344 in Biodiversidad, conservación y manejo en la región de la Reserva de la Biosfera Estación Biológica del Beni, Bolivia. SI/MAB Series 4. Smithsonian Institution, Washington, D.C., USA.

Rao, M. R., and R. B. Rajeswara Rao. 2006. Medicinal plants in tropical homegardens. Pages 205-232 in B. M. Kumar and P. K. R. Nair, editors. Tropical homegardens: a time-tested example of sustainable agroforestry. Springer, Dordrecht, The Neatherlands. http://dx.doi.org/10.1007/978-1-4020-4948-4 12

Reyes-García, V., R. Godoy, V. Vadez, L. Apaza, E. Byron, T. Huanca, W. R. Leonard, E. Pérez, and D. Wilkie. 2003. Ethnobotanical knowledge shared widely among Tsimane' Amerindians, Bolivia. Science 299(5613):1707. http://dx.doi. org/10.1126/science.1080274 
Reyes-García, V., J. L. Molina, L. Calvet-Mir, L. Aceituno-Mata, J. J. Lastra, R. Ontillera, M. Parada, M. Pardo-de-Santayana, M. Rigat, J. Vallès, and T. Garnatje. 2013. "Tertius gaudens": germplasm exchange networks and agroecological knowledge among home gardeners in the Iberian Peninsula. Journal of Ethnobiology and Ethnomedicine 9(1):53-62. http://dx.doi. org/10.1186/1746-4269-9-53

Reyes-García, V., V. Vadez, T. Huanca, W. Leonard, and D. Wilkie. 2005. Knowledge and consumption of wild plants: a comparative study in two Tsimane' villages in the Bolivian Amazon. Ethnobotany Research and Applications 3:201-207. [online] URL: http://journals.sfu.ca/era/index.php/era/article/ view/71/58.

Reyes-García, V., S. Vila, L. Aceituno-Mata, L. Calvet-Mir, T. Garnatje, A. Jesch, J. J. Lastra, M. Parada, M. Rigat, J. Vallès, and M. Pardo-de-Santayana. 2010. Gendered homegardens: a study in three mountain areas of the Iberian Peninsula. Economic Botany 64(3):235-247. http://dx.doi.org/10.1007/s12231-010-9124-1

Salpeteur, M., H. Patel, A. L. Balbo, X. Rubio-Campillo, M. Madella, P. Ajithprasad, and V. Reyes-García. 2015. When knowledge follows blood: kin groups and the distribution of traditional ecological knowledge in a community of seminomadic pastoralists, Gujarat (India). Current Anthropology 56 (3):471-483. http://dx.doi.org/10.1086/681006

Sereni Murrieta, R. S., and A. M. G. A. Winklerprins. 2003. Flowers of water: homegardens and gender roles in a riverine caboclo community in the lower Amazon, Brazil. Culture and Agriculture 25(1):35-47. http://dx.doi.org/10.1525/cag.2003.25.1.35

Thomas, E., and P. Van Damme. 2010. Plant use and management in homegardens and swiddens: evidence from the Bolivian Amazon. Agroforestry Systems 80(1):131-152. http://dx.doi. org/10.1007/s10457-010-9315-X

Thompson, E. C., and J. Zhang. 2006. Comparative cultural salience: measures using free-list data. Field Methods 18 (4):398-412. http://dx.doi.org/10.1177/1525822x06293128

Voeks, R. A. 2004. Disturbance pharmacopoeias: medicine and myth from the humid tropics. Annals of the Association of American Geographers 94(4):868-888. http://dx.doi.org/10.1111/ j.1467-8306.2004.00439.x

Wasserman, S., and K. Faust. 1994. Social network analysis: methods and applications Cambridge University Press, Cambridge, UK. http://dx.doi.org/10.1017/cbo9780511815478

Wezel, A., and S. Bender. 2003. Plant species diversity of homegardens of Cuba and its significance for household food supply. Agroforestry Systems 57(1):39-49. http://dx.doi. org/10.1023/A:1022973912195

Wezel, A., and J. Ohl. 2005. Does remoteness from urban centres influence plant diversity in homegardens and swidden fields?: A case study from the Matsiguenka in the Amazonian rain forest of Peru. Agroforestry Systems 65(3):241-251. http://dx.doi. org/10.1007/s10457-005-3649-9
Yang, L., S. Ahmed, J. R. Stepp, K. Mi, Y. Zhao, J. Ma, C. Liang, S. Pei, H. Huai, G. Xu, A. C. Hamilton, Z.-W. Yang, and D. Xue. 2014. Comparative homegarden medical ethnobotany of Naxi healers and farmers in northwestern Yunnan, China. Journal of Ethnobiology and Ethnomedicine 10: 6. http://dx.doi. org/10.1186/1746-4269-10-6 


\section{Appendix 1.}

Table 1. List of species inventoried in homegardens in two Tsimane' villages. Uses code as Medicinal:M, Food:F, Artisanal:A, Other:O.

\begin{tabular}{|c|c|c|c|c|c|}
\hline $\begin{array}{l}\text { Vernacular } \\
\text { name }\end{array}$ & Scientific Name & Taxonomic Family & Source & Use & Code \\
\hline ajosh & & & & $\mathrm{M}, \mathrm{F}$ & 122002 \\
\hline apaijniquij & Pera benensis (Rusby) & Euphorbiaceae & 1 & $\mathrm{M}, \mathrm{O}$ & 122068 \\
\hline arara' & Urera laciniata (Goudot) Wedd urticaria & Urticaceae & $1,3,4$ & M & 122003 \\
\hline ashashaj & Citrus limon (L.) Burn & Rutaceae & 1,4 & $\mathrm{M}, \mathrm{F}$ & 122004 \\
\hline asuntena & & & & $\mathrm{M}, \mathrm{F}$ & 122001 \\
\hline ava-ava & Prockia crucis L. & Salicaceae & 3 & A & 122097 \\
\hline bäcäj-bäcäj & & & & $\mathrm{F}$ & 122005 \\
\hline bajna & Gossypium barbadeense L. & Malvaceae & 1,4 & $\mathrm{~A}, \mathrm{O}$ & 122006 \\
\hline banana & Musa $x$ acuminata & Musaceae & 1 & M & 122007 \\
\hline bejqui & Hymenaea courbaril L. & Leguminosae-Cae & $1,3,4$ & $\mathrm{M}, \mathrm{F}$ & 122008 \\
\hline binca & Passiflora triloba R.\&P. ex DC & Passifloraceae & 1 & $\mathrm{~F}$ & 122009 \\
\hline bira-bira & & & & M & 122010 \\
\hline buisi & Entada sp. & Leguminosae-Mim & 1 & M & 122011 \\
\hline buvui' & & & & $M, A$ & 122070 \\
\hline cafe & & & & $\mathrm{F}$ & 122012 \\
\hline caij & Ipomoea batatas & Convolvulaceae & 4 & $\mathrm{~F}$ & 122071 \\
\hline cajna & Bactris riparia & Palmae & 1 & $\mathrm{~F}$ & 122098 \\
\hline cashtira & & & & $\mathrm{F}$ & 122085 \\
\hline cebolla & & & & $\mathrm{F}$ & 122013 \\
\hline chipapa & & & & $\mathrm{F}$ & 122014 \\
\hline chirimolla & & & & $\mathrm{F}$ & 122015 \\
\hline chito' & Tephrosia vogelii J. D. & Leguminosae-Pap & $1,3,4$ & $\mathrm{O}$ & 122016 \\
\hline chocorati & Theobroma cacao L. & Sterculiaceae & 1 & $\mathrm{~F}$ & 122017 \\
\hline chorecho' & Aniba canelilla (H.B.K.) Mez & Lauraceae & 1,3 & M F & 122072 \\
\hline chujbubyty & Peperomia rotundifolia (L.) Kunth & Piperaceae & 1 & M & 122018 \\
\hline chura' & Swietenia macrophylla (King) & Meliaceae & 1 & $\mathrm{~A}, \mathrm{O}$ & 122073 \\
\hline $\operatorname{coco}$ & Cocos nucifera & Palmae & 1 & $\mathrm{~F}$ & 122019 \\
\hline cocob & & & & $\mathrm{F}, \mathrm{A}$ & 122099 \\
\hline cojco & Pachyrhizus tuberosus Spreng & Leguminosae-Pap & 1 & $\mathrm{~F}$ & 122020 \\
\hline conei & & & & $\mathrm{M}, \mathrm{A}, \mathrm{O}$ & 122100 \\
\hline corishi & & & & $F, A$ & 122025 \\
\hline $\cos ^{\prime}$ & Nicotina tabacum & Solanaceae & 1,4 & $\mathrm{M}, \mathrm{O}$ & 122021 \\
\hline coti' & Psidium guajava L. & Myrtaceae & $1,3,4$ & $\mathrm{M}, \mathrm{F}$ & 122022 \\
\hline cuimashi & & & & A & 122101 \\
\hline cu'na & Inga crestediona Benth ex Seeman & Leguminosae-Mim & 1,3 & $\mathrm{~F}$ & 122023 \\
\hline
\end{tabular}




\begin{tabular}{|c|c|c|c|c|c|}
\hline curi & Lantana cf. Aristat & Verbenaceae & 1,4 & $M, F$ & 122024 \\
\hline curij & Lantana cf. Aristat & Verbenaceae & 1 & $\mathrm{~F}$ & 122102 \\
\hline dabaj & Arachis hypogaea & Papilionaceae-Leg & 4 & $\mathrm{~F}$ & 122026 \\
\hline dyestsadyes & Baccharis trinervis (Lam) Pers. & Compositae & 1 & M & 122103 \\
\hline ere' & Petiveria alliacea $\mathrm{L}$. & Phytolaccaceae & 1,4 & M & 122027 \\
\hline erepa'/erepaj & Crescentia cujete & Bignoniaceae & 1,4 & $\mathrm{M}, \mathrm{A}, \mathrm{O}$ & 122028 \\
\hline faj/fa' & Bixa orellana L. & Bixaceae & 1 & $\mathrm{~F}, \mathrm{~A}, \mathrm{O}$ & 122029 \\
\hline frutilla & & & & $\mathrm{F}$ & 122107 \\
\hline guineo & Musa xacuminata & Musaceae & $\begin{array}{l}1 \\
1,2,3\end{array}$ & $\mathrm{~F}$ & 122085 \\
\hline ibijqui & Rheedia gardneriana Miers ex. Planch \&Triana & Clusiaceae & & $\mathrm{F}$ & 122031 \\
\hline i'fare & Brugmansia arborea & Solanaceae & 4 & M & 122030 \\
\hline ijmemej & Myrcia fallax & Myrtaceae-Leg & 4 & M & 122032 \\
\hline ij'sita & Pseudolmedia laevis (Ruiz \& Pavon) J.F. Macbr. & Moraceae & 1 & $\mathrm{~F}$ & 122074 \\
\hline irepij & Ocimum micranthum Willd. & Labiatae & 1,4 & M & 122033 \\
\hline irepij & Ocimum micranthum Willd. & Labiatae & 1 & M & 122075 \\
\hline ja'me & & & & $\mathrm{M}, \mathrm{A}, \mathrm{O}$ & 122076 \\
\hline $\operatorname{lima}$ & & & & $\mathrm{F}$ & 122034 \\
\hline limonara & Citrus limetta & Rutaceae & 1 & $\mathrm{~F}$ & 122035 \\
\hline macdarina & Citrus reticulata & Rutaceae & 1,4 & $\mathrm{~F}$ & 122038 \\
\hline manai' & Attalea phalerata C. Martius ex Sprengel & Palmae & $1,2,4$ & $\mathrm{~F}, \mathrm{O}$ & 122036 \\
\hline manco & Mangifera indica & Anacardiaceae & 1 & $\mathrm{~F}$ & 122037 \\
\hline manzana & & & & $\mathrm{F}$ & 122039 \\
\hline maraca & Citrus sinensis & Rutaceae & 1,4 & $\mathrm{~F}$ & 122040 \\
\hline marva & Sida rhombifolia L & Malvaceae & 1 & M & 122041 \\
\hline mature' & Acmella oleracea & Compositae & 4 & M & 122077 \\
\hline merique & Ananas comosus & Bromeliaceae & 4 & $\mathrm{~F}$ & 122042 \\
\hline mora & Maclura tinctoria & Moraceae & 4 & $\mathrm{~F}$ & 122078 \\
\hline morifi & Dichorisandra sp. & Commelinaceae & 3,4 & M & 122043 \\
\hline nonoj & Nectandra caucana & Lauraceae & 1 & $A, O$ & 122095 \\
\hline ña'me & Inga cf. ruiziana Don. & Leguminosae-Mim & 1,3 & $\mathrm{~F}, \mathrm{O}$ & 122094 \\
\hline ñapis & & & & M & 122096 \\
\hline ocoró & Rheedia acuminata (Ruiz \& Pavon) Planch. \& Triana & Clusiaceae & 1 & $\mathrm{~F}, \mathrm{~A}$ & 122045 \\
\hline onomaj & Passiflora sp. & Passifloraceae & 3 & A & 122079 \\
\hline oteti & & Amarillidaeceae & 1 & M & 122046 \\
\hline o'yi & Manihot esculenta & Euphorbiaceae & 4 & $\mathrm{~F}$ & 122044 \\
\hline pacay & Inga sp. & Leguminosae-Mim & 1 & $\mathrm{~F}$ & 122109 \\
\hline parta & Persea americana C. Miller & Lauraceae & 1 & $\mathrm{M}, \mathrm{F}, \mathrm{A}$ & 122047 \\
\hline pe're & Musa $\times$ balbisiana & Musaceae & 1 & $\mathrm{~F}$ & 122048 \\
\hline pofi & Carica papaya L. & Caricaceae & 1 & $\mathrm{~F}$ & 122049 \\
\hline potona & Kalanchoe pinnata (Lamark) Persoon & Crassulaceae & 1 & M & 122050 \\
\hline queru-queru & Ormosia nobilis & Fabaceae & 1 & A & 122108 \\
\hline
\end{tabular}




\begin{tabular}{|c|c|c|c|c|c|}
\hline ribo' & & & & $\mathrm{F}, \mathrm{A}$ & 122093 \\
\hline rosario & Coix lachryma-jobi & Gramineae & 4 & A & 122051 \\
\hline sapaio & & & & $\mathrm{F}$ & 122104 \\
\hline saute & Zingiber officinale & Zingiberaceae & 1,4 & $M, F$ & 122052 \\
\hline sebiria & Cymbopogon citratus & Gramineae & 1 & $\mathrm{M}, \mathrm{F}, \mathrm{O}$ & 122053 \\
\hline shabai & & & & $\mathrm{F}$ & 122080 \\
\hline shandia & Citrullus lanatus & Cucurbitaceae & 1 & $\mathrm{~F}$ & 122054 \\
\hline shepi & Gallesia integrifolia (Sprengel) Harms & Phytolaccaceae & 1,4 & $\mathrm{M}, \mathrm{O}$ & 122111 \\
\hline shepi'is & Mansoa alliacea (Lamark) A. Gentry & Bignoniaceae & 1 & $\mathrm{M}, \mathrm{F}, \mathrm{A}$ & 122081 \\
\hline shishivutuij & & & & $\mathrm{M}$ & 122091 \\
\hline shuru' & Gynerium sagittatum (Aublet) P Beauv. & Gramineae & $1,3,4$ & $\mathrm{~F}, \mathrm{~A}$ & 122056 \\
\hline sicoco' & Chenopodium ambrosioides & Chenopodiaceae & 4 & M & 122110 \\
\hline siyamo & Cedrela odorata L. & Meliaceae & 1,3 & $\mathrm{M}, \mathrm{A}, \mathrm{O}$ & 122082 \\
\hline ta' & Capsicum sp. & Solanaceae & 1,4 & $\mathrm{~F}, \mathrm{O}$ & 122055 \\
\hline tamtac & Pilocarpus sp. & Rutaceae & 3 & $\mathrm{M}, \mathrm{F}$ & 122057 \\
\hline ta'ra & & & & $\mathrm{F}$ & 122056 \\
\hline toronja & Citrus paradisi Macf. & Rutaceae & 1,4 & $\mathrm{~F}$ & 122058 \\
\hline totop & Passiflora sp. & Passifloraceae & 3 & $\mathrm{~F}$ & 122059 \\
\hline tsocon & Rheedia acuminata (Ruiz \& Pavon) Planch. \& Triana & Clusiaceae & 1,2 & $\mathrm{~F}$ & 122060 \\
\hline tsocon & Rheedia cf. brasiliensis (Mart.) Planch. \& Triana & & 3 & & 122060 \\
\hline tyi'/pa'ñe & Genipa americana L. & Rubiaceae & 1,2 & M & 122061 \\
\hline tyutyura' & Mauritia flexuosa & Palmae & 1,3 & $\mathrm{~F}, \mathrm{O}$ & 122090 \\
\hline u'puyu & Piper laevigatum Kunth & Piperaceae & 1,3 & M & 122089 \\
\hline vadaca & Passiflora sp. & Passifloraceae & 1,3 & $\mathrm{~F}$ & 122083 \\
\hline väij & Bactris gasipaes H.B.K. & Palmae & 1,4 & $\mathrm{~F}, \mathrm{~A}, \mathrm{O}$ & 122062 \\
\hline varosa & Xanthosoma sp. & Araceae & 1 & $\mathrm{~F}$ & 122084 \\
\hline vina'j & Stylogyne cauliflora (Mart \& Miq.) Mez & Myrsinaceae & 1,3 & $\mathrm{~F}$ & 122064 \\
\hline vira' vira' & Cymbopogon citratus & Gramineae & 1 & & 122053 \\
\hline virij & & & & $\mathrm{F}$ & 122088 \\
\hline viroj & & & & $\mathrm{F}$ & 122065 \\
\hline virui' & Inga sp. & Leguminosae-Mim & 1,3 & $\mathrm{O}$ & 122066 \\
\hline vishirij & Inga punctata Willd. & Leguminosae-Mim & 1 & $\mathrm{~F}$ & 122087 \\
\hline viyucure & & & & M & 122067 \\
\hline vo'codyes & Jatropha curcas L. & Euphorbiaceae & 1,3 & M & 122086 \\
\hline vujnare & & & & $\mathrm{M}, \mathrm{O}$ & 122106 \\
\hline $\begin{array}{l}\text { winsi winsi } \\
\text { vaivare }\end{array}$ & $\begin{array}{l}\text { Cardiospermum halicacabum } \\
\text { Eleuthernine citriodora Rav. }\end{array}$ & $\begin{array}{l}\text { Sapindaceae } \\
\text { Iridaceae }\end{array}$ & $\begin{array}{l}1 \\
1\end{array}$ & $\begin{array}{l}\mathrm{A} \\
\mathrm{M}\end{array}$ & $\begin{array}{l}122063 \\
122105\end{array}$ \\
\hline
\end{tabular}


References consulted for linking vernacular names to scientific names:

${ }^{1}$ Reyes-García, V. 2001. Indigenous people, ethnobotanical knowledge, and market economy. A case study of the Tsimane' Amerindians in lowland Bolivia. PhD Thesis, University of Florida.

${ }^{2}$ Huanca, T. 1999. Tsimane' Indigenous Knowledge. Swidden Fallow Management andConservation. PhD Thesis, University of Florida.

${ }^{3}$ Guéze, M. 2011. Evaluation of tree diversity and utilization: the role of acculturation. A case study in the Bolivian Amazaon. PhD Thesis, Institut de Ciéncia i Tecnologia Ambientals, Universitat Autònoma de Barcelona.

${ }^{4}$ Ticona, J.P. 2010. Los chimane: conocimiento y uso de plantas medicinales en la comunidad de Tacuaral del Matos, Provicia Ballivian, Departamento del Beni. Bachelor Thesis, Universidad Mayor de San Andrés. 